\title{
Rethinking the locked-in state for people with ALS
}

Steven M. Albert, PhD, and Paul Wicks, PhD

Neurology ${ }^{\circledR}$ 2019;93:419-420. doi:10.1212/WNL.0000000000008055

An important study by Kuzma-Kozakiewicz et al. ${ }^{1}$ found that people with locked-in syndrome resulting from amyotrophic lateral sclerosis (ALS) report reasonable quality of life, surprisingly low levels of depressed mood, and a sustained commitment to living. Most remained satisfied with their decision to choose invasive ventilation and parenteral nutrition (percutaneous endoscopic gastrostomy $[\mathrm{PEG}]$ ) to maintain life. Strengths of the study include standardized assessments of mental health and psychosocial adaptation along with use of eye-tracking software to record responses to interview questions, a technology only recently available to patients.

The research team worked with Dignitas dolentium ("Dignity for those that suffer"), a Polish patient organization, to contact family caregivers of patients with ALS with locked-in syndrome $(\mathrm{n}=103)$. Caregivers of 25 patients responded and 19 were interviewed. Despite their severe disability and dependence on supportive technology, patients reported a range in quality of life that skewed positive. Eleven of the 19 indicated a positive score on the Anamnestic Comparative Self-Assessment, a measure from oncology that asks respondents to rate their quality of life at the present time compared to other times in their life. Seventeen of the 19 were satisfied with the decision to choose invasive technology and PEG, and only 2 reported a wish to hasten their death. Perhaps contrary to expectations, only a quarter met criteria for depressed mood. The majority of patients, then, were able to adjust well to the most severe disability of late-stage ALS. This successful reappraisal of quality of life in the face of severe disability is a strong demonstration of resilience and cognitive reframing as patients and their families readjust to the "new normal" at each step of progressive disease. It also raises the larger question of how best to speak of this stage of progressive neurodegenerative conditions. If a majority of patients with locked-in syndrome report reasonable quality of life, is it time to stop speaking of an ALS diagnosis as devastating? As technology increasingly wedges open the window of communication, is it time to abandon the terminology of the "locked-in state"?

Answering these questions will have substantial implications for clinical care and policy. Use of tracheostomy and mechanical ventilation varies considerably across countries, from a third of patients with ALS in Japan ${ }^{2}$ to $20.3 \%$ in South Korea, ${ }^{3} 16.3 \%$ in Italy, ${ }^{4}$ and only $8 \%$ in the United States. ${ }^{5}$ Is $33 \%$ too high or $8 \%$ too low? Are some patients, who could possibly adjust well to supportive care in locked-in states, not receiving this option because of assumptions made about the quality of their lives? The study from Kuzma-Kozakiewicz et al. suggests that few who choose the option regret the decision or fail to find some elements of quality with appropriate supportive care.

In fact, it is difficult to know what the prevalence of tracheostomy and mechanical ventilation is in many natural history cohorts, since tracheostomy, use of nasal ventilation for over $20-22 \mathrm{~h} / \mathrm{d}$, and death are often combined as a single endpoint in studies of disease progression. ${ }^{6}$ Combining these very different states assumes that severe disability requiring supportive care and death are equivalent. That may be so for declining respiratory function but clearly is not so for patients reflecting on the quality of their lives. The field's gold standard clinical outcome measure, the ALS Functional Rating Scale-Revised, ${ }^{7}$ has a clear floor effect, which was identified by a patient living

\author{
Correspondence \\ Dr. Albert \\ smalbert@pitt.edu
}

\section{RELATED ARTICLE}

An observational study on quality of life and preferences to sustain life in locked-in state

Page 425 
with ALS who was herself quadriplegic and yet designed a psychometric study to extend the scale using only her eyeblink communicator. ${ }^{8}$

However, if Kuzma-Kozakiewicz et al. have shown that some patients are able to adjust well to locked-in states, their study cannot tell us how generalizable this response is. A potential source of bias was the critical role of family caregivers, who received the invitation to participate. It is possible that families who responded to the call to participate represent a selected sample of the best-adjusted patients, with the most optimal caregiving arrangements. These are likely to be families that had planned for eventual tracheostomy and mechanical ventilation or who had the resilience to respond positively. Indeed, only 2 of the 19 cases reported that the tracheostomy was not planned. The study does not appear to have collected caregiver data that would clarify whether patients participating or not were similar in these features of caregiving or in the consequences of caring for a person in this state long-term.

Another potential bias is patient commitment to tracheostomy after the fact. The late Lewis Rowland, MD, would often raise this point, wondering how someone who had made this decision could question it given the intense commitment of care it requires. It is possible that patients with tracheostomy who were unable to cope well would not appear in this sample because they discontinued use and subsequently died.

Kuzma-Kozakiewicz et al. should be commended for a careful investigation, but a larger epidemiologic study following a cohort from the point of tracheostomy forward is required to settle what proportion of patients is able to adapt well to mechanical ventilation and locked-in states. Such a cohort study would likely find large differences between people with planned and unplanned use of mechanical ventilation. It would also shed light on what proportion of people choosing mechanical ventilation ultimately discontinue use. At the very least, the research of Kuzma-Kozakiewicz et al. encourages us to reflect on our preconceptions and prejudices. In a research field concerned primarily with slowing progression, we might reflect on whether we are devoting enough energies to the preservation of dignity for those in later stages of disease.

\section{Study funding}

No targeted funding reported.

\section{Disclosure}

P.W. is a caregiver to a person living with ALS. Go to Neurology.org/N for full disclosures.

\section{References}

1. Kuzma-Kozakiewicz M, Andersen PM, Ciecwierska K, et al. An observational study on quality of life and preferences to sustain life in locked-in state. Neurology 2019;93: e938-e945.

2. Tagami M, Kimura F, Nakajima $\mathrm{H}$, et al. Tracheostomy and invasive ventilation in Japanese ALS patients: decision-making and survival analysis: 1990-2010. J Neurol Sci 2014;344:158-164.

3. Jun KY, Park J, Oh KW, et al. Epidemiology of ALS in Korea using nationwide big data. J Neurol Neurosurg Psychiatry 2019;90:395-403.

4. Ceriana P, Surbone S, Segagni D, Schreiber A, Carlucci A. Decision-making for tracheostomy in amyotrophic lateral sclerosis (ALS): a retrospective study. Amyotroph Lateral Scler Frontotemporal Degener 2017;18:492-497.

5. Qadri S, Langefeld CD, Milligan C, Caress JB, Cartwright MS. Racial differences in intervention rates in individuals with ALS: a case-control study. Neurology 2019;92: e1969-e1974.

6. Andrews JA, Meng L, Kulke SF, et al. Association between decline in slow vital capacity and respiratory insufficiency, use of assisted ventilation, tracheostomy, or death in patients with amyotrophic lateral sclerosis. JAMA Neurol 2018;75:58-64.

7. Cedarbaum JM, Stambler N, Malta E. The ALSFRS-R: a revised ALS functional rating scale that incorporates assessments of respiratory function. J Neurol Sci 1999;169: 13-21.

8. Wicks P, Massagli MP, Wolf C, Heywood J. Measuring function in advanced ALS: validation of the ALSFRS-EX extension items. Eur J Neurol 2009;16:353-359. 


\section{Neurology}

\section{Rethinking the locked-in state for people with ALS \\ Steven M. Albert and Paul Wicks}

Neurology 2019;93;419-420 Published Online before print August 7, 2019

DOI 10.1212/WNL.0000000000008055

This information is current as of August 7, 2019

\section{Updated Information \& Services}

References

Citations

Subspecialty Collections

Permissions \& Licensing

Reprints including high resolution figures, can be found at: http://n.neurology.org/content/93/10/419.full

This article cites 8 articles, 3 of which you can access for free at: http://n.neurology.org/content/93/10/419.full\#ref-list-1

This article has been cited by 1 HighWire-hosted articles: http://n.neurology.org/content/93/10/419.full\#\#otherarticles

This article, along with others on similar topics, appears in the following collection(s):

Amyotrophic lateral sclerosis

http://n.neurology.org/cgi/collection/amyotrophic_lateral_sclerosis_ Decision analysis

http://n.neurology.org/cgi/collection/decision_analysis

Palliative care

http://n.neurology.org/cgi/collection/palliative_care

Quality of life

http://n.neurology.org/cgi/collection/quality_of_life

Information about reproducing this article in parts (figures,tables) or in its entirety can be found online at:

http://www.neurology.org/about/about_the_journal\#permissions

Information about ordering reprints can be found online:

http://n.neurology.org/subscribers/advertise

Neurology ${ }^{\circledR}$ is the official journal of the American Academy of Neurology. Published continuously since 1951, it is now a weekly with 48 issues per year. Copyright @ 2019 American Academy of Neurology. All rights reserved. Print ISSN: 0028-3878. Online ISSN: 1526-632X.

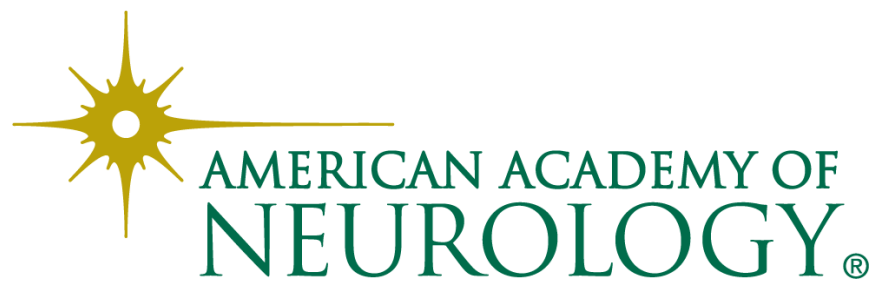

